\title{
Quantitative, structural and molecular changes in neuroglia of aging mammals: A review
}

\section{Ennio Pannese}

Emeritus, Full Professor of Normal Human Anatomy and Neurocytology at the University of Milan, Italy

The neuroglia of the central and peripheral nervous systems undergo numerous changes during normal aging. Astrocytes become hypertrophic and accumulate intermediate filaments. Oligodendrocytes and Schwann cells undergo alterations that are often accompanied by degenerative changes to the myelin sheath. In microglia, proliferation in response to injury, motility of cell processes, ability to migrate to sites of neural injury, and phagocytic and autophagic capabilities are reduced. In sensory ganglia, the number and extent of gaps between perineuronal satellite cells - that leave the surfaces of sensory ganglion neurons directly exposed to basal lamina - increase significantly. The molecular profiles of neuroglia also change in old age, which, in view of the interactions between neurons and neuroglia, have negative consequences for important physiological processes in the nervous system. Since neuroglia actively participate in numerous nervous system processes, it is likely that not only neurons but also neuroglia will prove to be useful targets for interventions to prevent, reverse or slow the behavioral changes and cognitive decline that often accompany senescence.

Key words: Aging; astrocytes; microglia; neuroglia; oligodendrocytes; satellite cells; Schwann cells.

Correspondence: Ennio Pannese, Viale San Michele del Carso 15, 20144 Milan, Italy. Tel. +39.02.435854. E-mail: ennio.pannese@unimi.it

Key words: Aging; astrocytes; microglia; neuroglia; oligodendrocytes; satellite cells; Schwann cells.

Disclosures: The author reports no conflict of interest. The author received no grant from any funding agency in the public, commercial or not-for-profit sectors to support the preparation and publication of this review. 


\section{Introduction}

The human population has aged markedly over recent decades, and this has been accompanied by increased interest in understanding the aging process. Many studies have focused on nervous system aging and the aging of neurons in particular. By contrast, the aging of neuroglia cells has received somewhat less attention, probably in part because these cells were long considered to play a passive role in nervous system function, serving only to fill the gaps between neurons and hold them in place. However, more recent research has shown that neuroglia cells perform an extensive set of functions; for example, in the central nervous system they regulate homeostasis in the extracellular environment, provide metabolic support to neurons, modulate neuronal activity, support the long-term integrity of myelinated axons, are involved in the formation, function and plasticity of synapses, and in the peripheral nervous system they carry out neuroprotective functions and influence neuronal shape (e.g., see the following reviews: ${ }^{1-8}$ ). The aim of the present review is to survey the quantitative, structural and molecular changes that occur to the neuroglia of humans and other mammals during normal aging.

\section{Astrocytes}

With age, astrocytes undergo changes in morphology, structure, number, molecular profile and function. In aged humans, astrocytes have enlarged bodies, and more numerous, shorter and thicker processes, than in young adults. Astrocyte hypertrophy is more prominent in the white matter than gray matter, and its extent varies across nervous system regions. ${ }^{9}$ Hypertrophic astrocytes have been reported at the following sites: rat hippocampus; ${ }^{10-12}$ areas of the cerebral cortex, ${ }^{13,14}$ subcortical white matter, ${ }^{15}$ and optic nerve ${ }^{16}$ of monkey, and human cerebellum. ${ }^{17}$ The astrocytic processes that form the glia limiting membrane (glia limitans) are much more numerous in old than young monkeys, so the glia limitans is much thicker in older animals. ${ }^{13,18}$

One of the most prominent changes observed in astrocytes during aging is increase in number of intermediate filaments, which has been observed, for example, in rat hippocampus, ${ }^{10-12}$ and in cerebral cortex, ${ }^{13,18}$ subcortical white matter, ${ }^{15}$ optic nerve, ${ }^{16}$ and anterior commissure ${ }^{19}$ of monkey. Increased number of intermediate filaments is paralleled by enhanced expression of glial fibrillary acidic protein, and its mRNA (see the references in Table 1).

With advancing age, astrocytes also accumulate dense inclusions within their cytoplasm, presumably through phagocytosis. ${ }^{13,20}$ Sometimes these inclusions are derived from the degeneration of axon terminals and dendritic processes that occurs during aging. In other cases components of these inclusions are labeled with antibodies to myelin basic protein; it has therefore been suggested that, in old age, astrocytes participate in the phagocytosis of degenerating myelin. ${ }^{21}$ Astrocytes also accumulate lipofuscin with age (e.g., see ${ }^{18,20,22}$ ). Age-related changes to the nuclear morphology of astrocytes have been observed in mouse neostriatum, ${ }^{22}$ rat neurohypophysis (pituicytes), ${ }^{23}$ and rat supraoptic nucleus. ${ }^{24}$

Round bodies of varying size (5-20 $\mu \mathrm{m}$ or more in diameter), called corpora amylacea, may sometimes be present in astrocyte cytoplasm and as extracellular deposits in normal aged humans. These bodies, which are basophilic and periodic-acid-Schiff-positive, have no limiting membrane, and consist of randomly arranged filaments, among which a dense, flocculent material is interspersed; they are made up of a glucose polymer and small amounts of proteins. The origin of corpora amylacea is unclear, and it is unknown whether they are harmful to astrocytes or neurons..$^{25-27}$
With regard to the question as to whether astrocyte number changes with aging, no significant changes were found in rat and mouse hippocampus, ${ }^{12,28-30}$ rat supraoptic nucleus, ${ }^{24}$ rat auditory cortex, ${ }^{20}$ human neocortex, ${ }^{31,32}$ or visual cortex, ${ }^{13,14,33}$ prefrontal cortex, ${ }^{18}$ optic nerve, ${ }^{16}$ anterior commissure, ${ }^{19}$ and fornix ${ }^{34}$ of monkey. However, age-related increases in astrocyte number have been reported in human cerebral cortex, ${ }^{35}$ the molecular layer of rat dentate gyrus, ${ }^{36}$ rat parietal cortex, ${ }^{37}$ female mouse hippocampal dentate gyrus, ${ }^{38}$ and mouse basal ganglia. ${ }^{39}$ Conversely an age-related decrease in astrocyte number has been reported in the fimbria and ventral commissure of mouse. ${ }^{39}$ These contrasting findings might suggest that changes, if their occur, depend on species and brain region. However, some of these studies did not make allowance for the greater shrinkage of young nervous tissue, compared to old tissue, that occurs during preparation for examination, ${ }^{40}$ so that sections from young animals show greater cell density than those from old animals. It is also noteworthy that the sophistication (and likely accuracy) of the methods used to count astrocytes varied considerably between studies. To complicate matters further, an indepth study of circumscribed regions of mouse hippocampus found that astrocyte number increased with age in the stratum lacunosum-moleculare of the dorsal part of Ammon's horn but decreased with age in the stratum oriens of Ammon's horn. So, the total number of astrocytes in the whole area of the hippocampus did not change with age. ${ }^{41}$ It is possible that such 'give-and-take' changes also occur in other regions of the nervous system. Astrocytes have also been reported to occur grouped in clusters in the hippocampus of old rats. ${ }^{11}$

In the aging central nervous system, astrocytes and microglia are involved in the formation of amyloid beta $(A \beta)$ plaques, formerly known as senile or neuritic plaques (for a review, see ${ }^{42}$ ). These plaques consist of extracellular aggregates of fibrillar or non-fibrillar $A ß$ protein surrounded by degenerating axons and dendrites, astrocytes and microglia. They were found in the cortex and basal ganglia of several healthy aged mammals, including humans, dogs, cats, rats, and monkeys; they are particularly numerous in the brains of humans with neurodegenerative diseases.

A number of molecules upregulated or downregulated in the astrocytes of healthy aged animals are listed in Tables 1 and 2 .

An important function of astrocytes is to clear glutamate from the extracellular space at synapses, by means of the glutamate transporters and ionotropic glutamate receptors, present on astrocyte cell surfaces. The functional expression of ionotropic glutamate receptors varies with age. In the mouse, receptor density increases several folds between 1 month and 3-6 months of age to then decline rapidly, so that in old mice (21 months) receptor density is similar to that in 1-month-old animals. ${ }^{43}$

Gap junction connections between astrocytes are important for signaling. The astrocytes of old mice continue to express high levels of gap junction proteins, although a tendency to reduced interastroglial coupling has been reported. ${ }^{44,45}$ Also in old mice, astrocytes conserve their ability to express spontaneous and neurotransmitter-dependent intracellular $\mathrm{Ca}^{2+}$ signals. Gliotransmission resting levels, and astrocyte-neuron interactions are also largely conserved in old mice. ${ }^{46}$ Antioxidant capacity and glutathione metabolism are preserved from mature adulthood into senescence in mouse astrocytes. ${ }^{47}$

Astrocytes are important synthesizers of cholesterol within the central nervous system. However, cholesterol synthesis declines with age in astrocytes and this may adversely affect neurons, which rely on cholesterol from astrocytes (e.g., see $\left.{ }^{48}\right)$. This decline also has negative effects on myelin production by oligodendrocytes resulting in changes in peri-axonal myelin sheaths (see para- 
grapgh Oligodendrocytes and myelin). These changes are in turn responsible for reduced conduction velocities along axons, which may contribute to cognitive decline in aging. As noted previously, the expression of glial fibrillary acidic protein is increased in aged astrocytes (see also references in Table 1). Since increased expression of this protein is a characteristic of reactive astrocytes, aging astrocytes partially resemble reactive astrocytes - as also suggested by studies which found that aging astrocytes have a gene expression profile partially resembling that of reactive astrocytes. ${ }^{49,50}$

Astrocytes supply neurons with lactate as an additional energy substrate. ${ }^{51}$ The astrocytic genes involved in lactate regulation are unaltered with age ${ }^{49}$ suggesting that astrocytes are still capable to perform this function during aging. At the end of the $19^{\text {th }}$ century, astrocytes were classified by morphology and location into protoplasmic and fibrous types, found mainly in gray and white matter, respectively. ${ }^{52}$ Recent studies show that astrocytes also vary in terms of molecular profile, physiology and metabolism, and are hence far more heterogeneous than once suspected (e.g., see ${ }^{53-56}$ ). It is possible that the various subtypes of astrocytes change in different ways with aging, and this might contribute to explaining the markedly heterogeneous picture that emerges from studies on astrocyte aging. Future studies which take account of the different subtypes of astrocytes, may be expected to produce a more coher- ent picture of senescent changes in these cells.

\section{Oligodendrocytes and myelin}

It has been estimated that the plasma membrane of a myelinating oligodendrocyte may reach a surface area of $20 \times 10^{5} \mu \mathrm{m}^{2}$. The production and support of so much membrane require enormous metabolic load and imply the production of abundant toxic byproducts. Furthermore, since iron is a cofactor for many of the enzymes involved in myelin synthesis, oligodendrocytes have large iron stores which are a potential source of free radicals. Oligodendrocytes are, in fact, much more vulnerable to oxidative damage than other nervous system cells (for a review, see ${ }^{57}$ ) and are strongly affected by aging.

In old age, some oligodendrocytes develop thick processes with bulbous enlargements. Dense inclusions are often present in the cell body and in the bulbous enlargements. ${ }^{16,58}$ These inclusions have irregular shapes and can be as large as $1 \mu \mathrm{m}$ in diameter. Some are composed of homogeneously dense material; others contain patches of a lower density component embedded in the dense material. Sometimes the lower density component appears to consist of stacks of thin lamellae. Oligodendrocytes are not generally thought to have phagocytic activity, so those containing such inclusions are likely to be breaking down and resorbing their own myelin sheaths. ${ }^{59}$ Some oligodendrocytes degenerate during

Table 1. A list of molecules that are upregulated in the astrocytes of healthy aged animals.

\begin{tabular}{llr}
\hline Astrocyte marker & Species & References \\
Glial fibrillary acidic protein (GFAP) & Mouse and rat & 137 \\
& Mouse (female) & $24,87,139,140$ \\
& Rat & 141 \\
GFAP mRNA & Human & 142 \\
& Rat and human & 138 \\
& Mouse (female) & 143 \\
\hline S100ß (Calcium binding protein) & Rat & 144 \\
Vimentin & Human & 24 \\
& Rat & 141 \\
\hline Apolipoprotein E, apolipoprotein J (clusterin), & Human & 87 \\
Complement 3 receptor (OX42), heme oxygenase-1, & Rat & \\
Major histocompatibility complex II antigen (OX6), & & 49,50 \\
Transforming growth factor- $\beta 1$ & & Mouse \\
Components C3 and C4B of the complement system & & 50 \\
\hline Cytokines & Mouse & 49 \\
CXCL10/inducible protein-10 (IP-10) & Mouse & 49,50 \\
CXCL5 & Mouse & 49 \\
Serpina 3 (serine protease inhibitor) & Mouse & \\
\hline Cholesterol-transporting proteins & & \\
\hline
\end{tabular}

Table 2. A list of molecules that are downregulated in the astrocytes of healthy aged animals.

\begin{tabular}{llc} 
Astrocyte marker & Species & References \\
Aquaporin-4 & Mouse & 145,146 \\
Ampa receptors & Mouse & 43 \\
\hline ATP & Mouse & 147 \\
Fibroblast growth factor 2 (FGF2) & Rat & 148 \\
\hline Vascular endothelial growth factor (VEGF) & Rat & 148 \\
Brain derived neurotrophic factor (BDNF); Glial derived neurotrophic factor (GDNF) & Rat (in culture) & 149 \\
\hline Cholesterol synthesis enzymes & Mouse & 49 \\
\hline
\end{tabular}


aging, and new oligodendrocytes are produced. If these two processes are balanced, cell number remains constant, while imbalance may lead to an increase or decrease in oligodendrocyte number. Available findings are that oligodendrocyte number does not change significantly with age in the auditory ${ }^{20}$ and prefrontal ${ }^{18}$ cortices of rat, and anterior commissure ${ }^{19}$ of monkey; but it increases in the optic nerve, ${ }^{16}$ visual cortex, ${ }^{14,33}$ and fornix ${ }^{34}$ of monkey, and visual and auditory cortices of the mouse; ${ }^{60}$ and decreases in human neocorte $\mathrm{x}^{31,32}$ and rat subcortical white matter. ${ }^{61}$ These findings suggest that the age-related changes to the oligodendrocyte number vary with species and brain region. However, as was the case for astrocytes (see paragraph Astrocytes), the large methodological variation among studies precludes definitive conclusions.

As regards the origin of new oligodendrocytes, the prevailing view is that mature oligodendrocytes do not divide, ${ }^{62}$ and that new oligodendrocytes originate from progenitor cells present in white and gray matter. Whereas in young age oligodendrocytes usually occur singly, in old age they often occur in pairs, rows or clusters, ${ }^{33,59}$ interpreted as the result of recent cell division.

Alterations to oligodendrocytes are often accompanied by degenerative changes to associated myelin sheaths. ${ }^{63}$ A common age-related degenerative change to myelin is local splitting of the major dense line with enclosure of a pocket of cytoplasm within the split. ${ }^{64}$ This pocket of cytoplasm, which probably belongs to the oligodendrocyte that formed the sheath, appears to be degenerating, as it is dense and often contains amorphous dense bodies. ${ }^{64}$ Bleb formation is another type of age-related degenerative change to myelin sheaths. Blebs, which have round profiles and may be up to $10 \mu \mathrm{m}$ in diameter, ${ }^{65}$ are produced by splitting of the intraperiod line of compact myelin. Changes to myelin contribute to a decrease in white matter volume that occurs in advanced age ${ }^{66,67}$ Other agerelated changes to myelin are occurrence of sheaths of redundant myelin, ${ }^{68}$ appearance of circumferential splits in thick sheaths, ${ }^{64}$ and increased percentage of thin sheaths (e.g., see ${ }^{21}$ ). These changes indicate that myelin continues to form in old age. In fact, degeneration of myelin internodes is followed by remyelination. ${ }^{21}$ However, remyelination becomes less efficient with advancing age ${ }^{69,70}$ because the regenerative capacity of oligodendrocyte progenitor cells decreases, ${ }^{71}$ the ability of oligodendrocytes to produce myelin declines, and also because they may not receive sufficient cholesterol from astrocytes. Degenerated myelin internodes are replaced by internodes which are shorter than pre-existing ones. Since myelin insulates axons and ensures rapid propagation of axon potentials, formation of shorter internodes, in combination with alterations to the myelin sheath, lead to reduced conduction velocities along the involved axons (e.g., see $\left.{ }^{72}\right)$. Velocity reductions have been recorded in the central nervous system of old humans and other animals. ${ }^{73-76}$ It is likely that reduced conduction velocity contributes to the cognitive decline often observed in old age $^{70,77}$

Much like astrocytes, oligodendrocytes are a heterogeneous cell population ${ }^{78}$ but whether the various subtypes of oligodendrocytes change in different ways with aging is not known.

\section{Microglia}

Notwithstanding reports to the contrary $\left(e . g ., \mathrm{see}^{79}\right)$, the prevailing opinion is that in healthy animals microglia are long-lived and have a low turnover rate. In mice, approximately half the microglia survive the entire animal lifespan. ${ }^{80}$ In humans, microglia renew slowly and some last for over two decades. ${ }^{81}$ The long lifespan of microglia increases the probability that they will be affected by aging. Aging is accompanied by morphological, molecular, and functional changes to microglia. Thus, microglia in normal aged animals have enlarged and rounded cell bodies, and less branched processes, than those in young adults (e.g., see ${ }^{60,82}$ ). Further, microglia with abnormally twisted, tortuous, and beading cytoplasmic processes have been found intermingled with microglia of normal aspect in the aged human brain. ${ }^{83}$ Finally, heterogeneous inclusions, including lipofuscin granules, accumulate with age in microglia; $;^{13,16,20,84,85}$ and in extremely advanced age, nearly all microglia contain perikaryal inclusions. ${ }^{60}$

It has been reported that the mean number of microglia does not change significantly with age in rat cortical area 2 of Krieg, ${ }^{86}$ rat dentate gyrus, ${ }^{87,88}$ rat olfactory bulb and cerebellum, ${ }^{89}$ and monkey visual cortex,${ }^{14}$ and fornix.${ }^{34}$ By contrast, microglia number is reported to increase significantly with age in rat auditory cortex, ${ }^{20}$ monkey optic nerve, ${ }^{16}$ mouse visual and auditory cortices, ${ }^{60}$ mouse fimbria and ventral commissure, ${ }^{39}$ female mouse hippocampus, ${ }^{38}$ and human female neocortex. ${ }^{32}$ These findings suggest that agerelated changes to microglia number vary markedly with brain region and species. However, the caveats regarding data on agerelated changes to astrocyte number (see paragraph Astrocytes) also apply to data on microglia. To complicate matters, age-related changes to microglia may also depend on gender. Thus, in two studies that used the same tissue processing and stereological methods, it was found that microglia number did not change with age in the hippocampus of male mice ${ }^{30}$ but increased significantly in the hippocampus of females. ${ }^{38}$

Microglia cells are closer to each other and less evenly distributed in aged than in young animals $\left(e . g .{ }^{20,38,60,90}\right)$. Once again, however, tissue shrinkage during sample preparation differs between old and young adult animals and could have contributed to reported differences in microglia distribution.

Proliferation in response to injury, ${ }^{91}$ motility of cell processes, ${ }^{82}$ ability to migrate to sites of neural injury, ${ }^{82}$ and phagocytic and autophagic capabilities ${ }^{92,93}$ are all reduced in the microglia of aged animals compared with young adults. Reduced dynamic behavior with age has been observed in microglia cultures. ${ }^{94}$ As noted in the paragraph Astrocytes, microglia are involved with astrocytes in the formation of $A ß$ plaques during aging. A number of molecules that are upregulated or downregulated in the microglia of healthy aged animals are listed in Tables 3 and 4 . From these tables it is evident that some findings are conflicting. Thus, in aged mice the expression of Toll-like receptors TLR 2 and TLR4 is upregulated according to Letiembre et al. ${ }^{95}$ but downregulated according to Caldeira et al. ${ }^{94}$ Similarly, the expression of anti-inflammatory cytokines in mice is upregulated according to Sierra et al..$^{84}$ and Henry et al. ${ }^{96}$ and downregulated according to $\mathrm{Ye}$ and Johnson. ${ }^{97}$

The decreased length and branching of processes, and the increased expression of inflammatory markers and cytokines, observed in aged microglia, are reminiscent of changes observed in activated microglia. Thus, it was once thought that microglia activation state increased with age (for reviews, see ${ }^{93,98,99}$ ). However, other changes that occur in microglia during normal aging (e.g., changed cytoplasmic structure, reduced ability to phagocytose and to migrate, decreased process motility, and changes in receptor expression) are not characteristic of activation and have been interpreted as an intrinsic expression of microglia aging $83,91,100$ that is accompanied by a decline in cell function.

Age-related decline in microglia function adversely affects neurons. In younger mice, microglia clear pathogens, aberrant proteins, and debris from the central nervous system by phagocytosis. Age-related decline in phagocytosis results in a more toxic environment which eventually impairs neuronal activity. Microglia processes are dynamic structures whose direct contact with neurons effects homeostatic regulation of neuronal activity. Highly 
active neurons release ATP, which induces microglia to migrate towards - and polarize their processes towards - these neurons. Microglia contact downregulates neuronal activity. The age-related reduction in microglia migration, process branching, and process motility, results in impaired homeostatic regulation of neuronal activity. Aging also results in imbalanced expression of receptors on microglia surfaces, which in turn may alter responses to environmental cues. Microglia responses to central nervous system injury, infection, disease or other perturbation can therefore become dysregulated with aging, and result in more severe neurodegeneration and functional impairment than would occur (due to perturbation) in younger animals..$^{99}$

\section{Ependymal cells, tanycytes, and choroid epitheli- um cells}

The age-related changes of these cells have been far less investigated compared to other neuroglia cells.

In aged mammals, ependymal cells are flattened and contain high numbers of intermediate filaments, dense bodies, large lipid droplets, and sometimes sparse Biondi bodies. Cilia are reduced in density and concentrated on a limited area of the apical surface (for a review, see ${ }^{101}$ ). With increasing age, tanycytes accumulate lipid droplets and bodies consisting of dense material and myelin figures (e.g., see $\left.{ }^{102}\right)$. Choroid epithelium cells become flattened and accumulate iron-positive inclusions, amyloid, and Biondi bodies with age ${ }^{103,104}$ Biondi bodies are cytoplasmic inclusions consisting of filaments, $8-10 \mathrm{~nm}$ in thickness, among which small lipid droplets and dense granules are interspersed. ${ }^{105-107}$ Biondi bodies are characteristic of aged humans; however, inclusions resembling Biondi bodies have been identified in the choroid epithelium of an aged chimpanzee. ${ }^{108}$ The origin and significance of these bodies are unclear. The age-related structural changes of choroid epithelium cells go together with a general reduction in the rate of cerebrospinal fluid turnover. ${ }^{109,110}$

Table 3. A list of molecules that are upregulated in the microglia of healthy aged animals.

\begin{tabular}{|c|c|c|}
\hline Microglial marker & Species & References \\
\hline Major histocompatibility complex class II (MHC II) antigens & $\begin{array}{l}\text { Human } \\
\text { Rat } \\
\text { Monkey }\end{array}$ & $\begin{array}{c}150,151 \\
88,89 \\
152\end{array}$ \\
\hline Macrophage antigen $\left(E_{1}\right)$ & Rat & 88,153 \\
\hline Leukocyte common antigen (LCA) & Rat & 88 \\
\hline Antibody OX6 & Rat & 89 \\
\hline Surface markers CD4, CD40 and CD86 & Rat & $87,88,154,155$ \\
\hline Surface markers CD11b (=complement receptor 3, CR3 and MAC1), CD11c and CD68 (=Macrosialin) & Mouse & $156-158$ \\
\hline \multirow[t]{2}{*}{ Toll-like receptors (TLRs) and CD14 } & Mouse & 95 \\
\hline & Rat & 159 \\
\hline Galectin-3 (=MAC-2) & Mouse & 160 \\
\hline Senescence-associated $\beta$-galactosidase (SA- $\beta$-GAL) & Mouse (in culture) & 94 \\
\hline Proinflammatory cytokines (IL1 $\alpha$, IL1 $\beta$, IL6, IL18, TNF $\alpha$ ) & $\begin{array}{l}\text { Human } \\
\text { Rat } \\
\text { Rat (in culture) } \\
\text { Mouse } \\
\text { Mouse (in culture) }\end{array}$ & $\begin{array}{c}161 \\
155,162,163 \\
164 \\
84,96 \\
97,165,166\end{array}$ \\
\hline Interferon- $\Upsilon$ (IFNY) & Rat & 154,155 \\
\hline Anti-inflammatory cytokines (IL10, TGF $\beta 1$ ) & Mouse & 84,96 \\
\hline Calpain-1 & Monkey & 167,168 \\
\hline Intercellular adhesion molecules (ICAM) & Rat & 155 \\
\hline Clusterin & Rat & 153 \\
\hline
\end{tabular}

Table 4. A list of molecules that are downregulated in the microglia of healthy aged animals.

\begin{tabular}{|c|c|c|}
\hline Microglial marker & Species & References \\
\hline Fractalkine receptor (CX3CR1) & Mouse (after lipopolysaccharide [LPS] challenge) & 169 \\
\hline Anti-inflammatory cytokines (IL4, IL10) & $\begin{array}{l}\text { Mouse (in culture) } \\
\text { Rat }\end{array}$ & $\begin{array}{c}97 \text { (however, see 84,96) } \\
162,170\end{array}$ \\
\hline Glutathione & Mouse & 165 \\
\hline Toll-like receptors & Mouse (in culture) & 94 (however, see 58,95 ) \\
\hline Nuclear factor NF-kB & Mouse (in culture) & 94 \\
\hline microRNA (miR-124 and miR-155) & Mouse (in culture) & 94 \\
\hline
\end{tabular}




\section{Schwann cells and their myelin sheaths}

The following age-related changes have been observed in Schwann cells: adaxonal cell processes sequestering portions of axoplasm, ${ }^{111}$ presence of residual bodies and myelin debris, ${ }^{112}$ and significant decrease in the mean percentage of cytoplasmic volume occupied by mitochondria. ${ }^{113}$ The latter change could lead to reduced energy availability in Schwann cells and to myelin alterations. Finally, in fowl Schwann cells, intranuclear inclusions are rare in young animals but common in old animals. ${ }^{114}$

Myelin alterations reported in the peripheral nervous system of aged individuals are similar to those observed in the central nervous system. They include segmental demyelination followed by remyelination (e.g. ${ }^{115-120}$ ), loss of myelin tightness (decompaction) due to the development of splits between lamellae, and presence of wide incisures and myelin loops. ${ }^{116,118}$ As in the central nervous system (see paragraph Astrocytes), these alterations may lead to reduced nerve conduction velocities. Such reductions have been observed in the peripheral nervous system of aged humans (e.g. $\left.{ }^{74,121-125}\right)$.

\section{Satellite cells in sensory ganglia}

In the sensory ganglia of adult vertebrates, each nerve cell body is usually enveloped by its own satellite cell sheath thus constituting a unit. ${ }^{126}$ This organization does not change with age. However, both the mean volume of the satellite cell sheath, and the mean ratio of satellite cell sheath volume to related nerve cell body volume, are significantly lower in old animals than in young adults. ${ }^{127,128}$ The reduction in satellite cell sheath volume is in part attributable to the significant decrease in satellite cell number that occurs in old age. ${ }^{129}$

With advancing age satellite cells undergo a number of changes (for a summary, see ${ }^{130}$ ). Thus, in rabbit spinal ganglia, both the total volume of the Golgi apparatus and the mean percentage of cytoplasmic volume occupied by this organelle decrease significantly - while the Golgi apparatus itself undergoes neither structural changes nor peripheral displacement. Furthermore, although mitochondrial structure does not change, mitochondrial size increases progressively and significantly with advancing age; while both mitochondrial mass and mean percentage of cytoplasmic volume occupied by mitochondria decrease progressively and significantly with age. Taken together, these findings suggest that the ability of satellite cells to produce energy metabolites decreases with age. The reduced ability of sensory neurons to respond to high energy demands in old age (e.g., see $\left.{ }^{131}\right)$ may be in part due to the diminished contribution of perineuronal satellite cells. With age, satellite cells accumulate lipofuscin. ${ }^{132}$ However, lipofuscin accumulation seems to have little or no effect on metabolism or functional activity of these cells.

Since satellite cells provide trophic and protective support to neurons, it is likely that the significant reduction in their number, mitochondrial mass, and ratio of satellite cell volume to nerve cell body volume, add up to reduced neuronal support, with negative consequences for neuronal activity. Furthermore, the number and extent of gaps between satellite cells, that leave the neuronal surface directly exposed to the basal lamina, significantly increase in old animals. ${ }^{128}$ For example, in rabbit spinal ganglia, for comparable neuronal perimeters, these gaps occur more than twice as often in old compared to young animals. In addition, while in young adults these gaps are no longer than $0.75 \mu \mathrm{m}$, in old rabbits they may be up to $7.7 \mu \mathrm{m}$. Since the nerve cells in sensory ganglia lack the protection of a vascular barrier such as is present in the central nervous system, only the satellite cell sheath controls the traffic of substances from the blood to the nerve cell body. Thus, the ganglionic nerve cells of old animals are more exposed, than those in young adults, to damage by harmful substances from the circulation.

In rabbit spinal ganglia, the gap junctions between perineuronal satellite cells - which are mainly composed of connexin43 increase in number with age, whereas the mean size of individual gap junctions remains constant. ${ }^{133}$ In spinal ganglia of the senescent mouse, both gap junction number and dye coupling between satellite cells increase, ${ }^{134}$ whereas connexin 43 expression decreases. ${ }^{135}$ These contrasting changes in the senescent mouse could be related to the presence of connexin types other than connexin 43 , in the gap junctions between the satellite cells of these animals.

\section{Closing remarks}

Over the last few decades knowledge of the structural and dynamic behavior changes that occur in neuroglia during normal aging has increased markedly. Knowledge of changes in molecular profiles has also increased, although many questions remain. More than in other organs, the various cells of the nervous system interact intimately with each other, so that age-related functional impairment in one cell type almost always affects the functioning of other cell types. We have seen, for example, that impaired cholesterol synthesis in aging astrocytes has negative effects on neuronal activity and on myelin production by oligodendrocytes, and also that the age-related functional decline in microglia cells damage neuronal activity. We can anticipate that continued study of interactions between the various cell types within the nervous system will be important for improving understanding of nervous system aging; particularly when combined with new experimental approaches such as advanced cell culturing, use of viral vectors, in situ glial imaging, and high content molecular analysis (for a review, see ${ }^{136}$ ). Since neuroglia participate actively in numerous nervous system processes, it is likely that not only neurons but also neuroglia will prove to be useful targets for interventions to prevent, reverse or slow the behavioral changes and cognitive decline that often accompany senescence. But to develop glia-targeting therapies it will be necessary to further improve understanding of the changes neuroglia undergo during normal aging.

\section{References}

1. Deitmer JW, Theparambil SM, Ruminot I, Noor SI, Becker HM. Energy dynamics in the brain: Contributions of astrocytes to metabolism and pH homeostasis. Front Neurosci 2019;13:1301.

2. Fan X, Agid Y. At the origin of the history of glia. Neuroscience 2018;385:255-71.

3. Magistretti PJ. Neuron-glia metabolic coupling and plasticity. J Exp Biol 2006;209:2304-11.

4. Parpura V, Heneka MT, Montana V, Oliet SH, Schousboe A, Haydon PG, et al. Glial cells in (patho)physiology. J Neurochem 2012;121:4-27.

5. Perea G, Sur M, Araque A. Neuron-glia networks: integral gear of brain function. Front Cell Neurosci 2014;8:378.

6. Sierra A, Paolicelli RC, Kettenmann H. Cien anos de microglía: Milestones in a century of microglial research. Trends Neurosci 2019;42:778-92.

7. Simons M, Nave KA. Oligodendrocytes: Myelination and axonal support. Cold Spring Harb Perspect Biol 2015;8:a020479.

8. Volterra A, Meldolesi J. Astrocytes, from brain glue to communi- 
cation elements: the revolution continues. Nat Rev Neurosci 2005;6:626-40.

9. Rodriguez JJ, Yeh CY, Terzieva S, Olabarria M, KulijewiczNawrot M, Verkhratsky A. Complex and region-specific changes in astroglial markers in the aging brain. Neurobiol Aging 2014:35:15-23.

10. Geinisman Y, Bondareff W, Dodge JT. Hypertrophy of astroglial processes in the dentate gyrus of the senescent rat. Am J Anat 1978;153:537-43.

11. Landfield PW, Rose G, Sandles L, Wohlstadter TC, Lynch G. Patterns of astroglial hypertrophy and neuronal degeneration in the hippocampus of ages, memory-deficient rats. J Gerontol 1977;32:3-12.

12. Lindsey JD, Landfield PW, Lynch G. Early onset and topographical distribution of hypertrophied astrocytes in hippocampus of aging rats: a quantitative study. J Gerontol 1979;34:661-71.

13. Peters A, Josephson K, Vincent SL. Effects of aging on the neuroglial cells and pericytes within area 17 of the rhesus monkey cerebral cortex. Anat Rec 1991;229:384-98.

14. Peters A, Verderosa A, Sethares C. The neuroglial population in the primary visual cortex of the aging rhesus monkey. Glia 2008;56:1151-61.

15. Sloane JA, Hollander W, Rosene DL, Moss MB, Kemper T, Abraham CR. Astrocytic hypertrophy and altered GFAP degradation with age in subcortical white matter of the rhesus monkey. Brain Res 2000;862:1-10.

16. Sandell JH, Peters A. Effects of age on the glial cells in the rhesus monkey optic nerve. J Comp Neurol 2002;445:13-28.

17. Alvarez MI, Rivas L, Lacruz C, Toledano A. Astroglial cell subtypes in the cerebella of normal adults, elderly adults, and patients with Alzheimer's disease: a histological and immunohistochemical comparison. Glia 2015;63:287-312.

18. Peters A, Sethares C. The effects of age on the cells in layer 1 of primate cerebral cortex. Cereb Cortex 2002;12:27-36.

19. Sandell JH, Peters A. Disrupted myelin and axon loss in the anterior commissure of the aged rhesus monkey. J Comp Neurol 2003;466:14-30.

20. Vaughan DW, Peters A. Neuroglial cells in the cerebral cortex of rats from young adulthood to old age: an electron microscope study. J Neurocytol 1974;3:405-29.

21. Peters A, Sethares C. Is there remyelination during aging of the primate central nervous system? J Comp Neurol 2003;460:23854.

22. Sturrock RR. A morphological study of the neostriatum of aged mice with particular reference to neuroglia. J Hirnforsch 1987;28:505-15.

23. Lafarga M, Andres MA, Berciano MT, Maquiera E. Organization of nucleoli and nuclear bodies in osmotically stimulated supraoptic neurons of the rat. J Comp Neurol 1991;308:329-39.

24. Berciano MT, Andres MA, Calle E, Lafarga M. Age-induced hypertrophy of astrocytes in rat supraoptic nucleus: a cytological, morphometric, and immunocytochemical study. Anat Rec 1995;243:129-44.

25. Hirano A. Neurons and astrocytes. In: RL Davis, DM Robertson, editors. Textbook of Neuropathology. 3rd ed. Baltimore: Williams \& Wilkins; 1997. p. 1-109.

26. Song W, Zukor H, Liberman A, Kaduri S, Arvanitakis Z, Bennett DA, et al. Astroglial heme oxygenase-1 and the origin of corpora amylacea in aging and degenerating neural tissues. Exp Neurol 2014;254:78-89.

27. Wisniewski HM, Terry RD. Morphology of the aging brain, human and animal. Prog Brain Res 1973;40:167-86.

28. Bhatnagar M, Cintra A, Chadi G, Lindberg J, Oitzl M, De Kloet ER, et al. Neurochemical changes in the hippocampus of the brown Norway rat during aging. Neurobiol Aging 1997;18:319-
27.

29. Grosche A, Grosche J, Tackenberg M, Scheller D, Gerstner G, Gumprecht A, et al. Versatile and simple approach to determine astrocyte territories in mouse neocortex and hippocampus. PLoS One 2013;8:e69143.

30. Long JM, Kalehua AN, Muth NJ, Calhoun ME, Jucker M, Hengemihle JM, et al. Stereological analysis of astrocyte and microglia in aging mouse hippocampus. Neurobiol Aging 1998;19:497-503.

31. Fabricius K, Jacobsen JS, Pakkenberg B. Effect of age on neocortical brain cells in 90+ year old human females-a cell counting study. Neurobiol Aging 2013;34:91-9.

32. Pelvig DP, Pakkenberg H, Stark AK, Pakkenberg B. Neocortical glial cell numbers in human brains. Neurobiol Aging 2008;29:1754-62.

33. Peters A, Sethares C. Oligodendrocytes, their progenitors and other neuroglial cells in the aging primate cerebral cortex. Cereb Cortex 2004; 14:995-1007.

34. Peters A, Sethares C, Moss MB. How the primate fornix is affected by age. J Comp Neurol 2010;518:3962-80.

35. Hansen LA, Armstrong DM, Terry RD. An immunohistochemical quantification of fibrous astrocytes in the aging human cerebral cortex. Neurobiol Aging 1987;8:1-6.

36. Pilegaard K, Ladefoged $\mathrm{O}$. Total number of astrocytes in the molecular layer of the dentate gyrus of rats at different ages. Anal Quant Cytol Histol 1996;18:279-85.

37. Peinado MA, Quesada A, Pedrosa JA, Torres MI, Martinez M, Esteban FJ, et al. Quantitative and ultrastructural changes in glia and pericytes in the parietal cortex of the aging rat. Microsc Res Tech 1998;43:34-42.

38. Mouton PR, Long JM, Lei DL, Howard V, Jucker M, Calhoun $\mathrm{ME}$, et al. Age and gender effects on microglia and astrocyte numbers in brains of mice. Brain Res 2002;956:30-5.

39. Ashraf A, Michaelides C, Walker TA, Ekonomou A, Suessmilch M, Sriskanthanathan A, et al. Regional distributions of iron, copper and zinc and their relationships with glia in a normal aging mouse model. Front Aging Neurosci 2019;11:351.

40. Haug H. Macroscopic and microscopic morphometry of the human brain and cortex. A survey in the light of new result. Brain Pathology 1984;1:123-49.

41. Jinno S. Regional and laminar differences in antigen profiles and spatial distributions of astrocytes in the mouse hippocampus, with reference to aging. Neuroscience 2011;180:41-52.

42. Walker LC. Aß plaques. Free Neuropathol 2020;1:31.

43. Lalo U, Palygin O, North RA, Verkhratsky A, Pankratov Y. Agedependent remodelling of ionotropic signalling in cortical astroglia. Aging Cell 2011;10:392-402.

44. Cotrina ML, Gao Q, Lin JH, Nedergaard M. Expression and function of astrocytic gap junctions in aging. Brain Res 2001;901:55-61.

45. Peters O, Schipke CG, Philipps A, Haas B, Pannasch U, Wang LP, et al. Astrocyte function is modified by Alzheimer's diseaselike pathology in aged mice. J Alzheimers Dis 2009;18:177-89.

46. Gomez-Gonzalo M, Martin-Fernandez M, Martinez-Murillo R, Mederos S, Hernandez-Vivanco A, Jamison S, et al. Neuronastrocyte signaling is preserved in the aging brain. Glia 2017;65:569-80.

47. Liddell JR, Robinson SR, Dringen R, Bishop GM. Astrocytes retain their antioxidant capacity into advanced old age. Glia 2010;58:1500-9.

48. Palmer AL, Ousman SS. Astrocytes and aging. Front Aging Neurosci 2018;10:337.

49. Boisvert MM, Erikson GA, Shokhirev MN, Allen NJ. The aging astrocyte transcriptome from multiple regions of the mouse brain. Cell Rep 2018;22:269-85. 
50. Clarke LE, Liddelow SA, Chakraborty C, Münch AE, Heiman $\mathrm{M}$, Barres BA. Normal aging induces A1-like astrocyte reactivity. Proc Natl Acad Sci USA 2018;115:E1896-E905.

51. Pellerin L, Bouzier-Sore AK, Aubert A, Serres S, Merle M, Costalat R, et al. Activity-dependent regulation of energy metabolism by astrocytes: an update. Glia 2007;55:1251-62.

52. Andriezen WL. The neuroglia elements in the human brain. $\mathrm{Br}$ Med J 1893;2:227-30.

53. John Lin CC, Yu K, Hatcher A, Huang TW, Lee HK, Carlson J, et al. Identification of diverse astrocyte populations and their malignant analogs. Nat Neurosci 2017;20:396-405.

54. Kohler S, Winkler U, Hirrlinger J. Heterogeneity of astrocytes in grey and white matter. Neurochem Res 2021;46:3-14.

55. Verkhratsky A, Nedergaard M. Physiology of astroglia. Physiol Rev 2018;98:239-389.

56. Zeisel A, Hochgerner H, Lönnerberg P, Johnsson A, Memic F, van der Zwan J, et al. Molecular architecture of the mouse nervous system. Cell 2018;174:999-1014.

57. McTigue DM, Tripathi RB. The life, death, and replacement of oligodendrocytes in the adult CNS. J Neurochem 2008;107:1-19.

58. Peters A. The node of Ranvier in the central nervous system. Q J Exp Physiol Cogn Med Sci 1966;51:229-36.

59. Peters A. Age-related changes in oligodendrocytes in monkey cerebral cortex. J Comp Neurol 1996;371:153-63.

60. Tremblay ME, Zettel ML, Ison JR, Allen PD, Majewska AK. Effects of aging and sensory loss on glial cells in mouse visual and auditory cortices. Glia 2012;60:541-58.

61. Chen L, Lu W, Yang Z, Yang S, Li C, Shi X, et al. Age-related changes of the oligodendrocytes in rat subcortical white matter. Anat Rec 2011;294:487-93.

62. Keirstead HS, Blakemore WF. Identification of post-mitotic oligodendrocytes incapable of remyelination within the demyelinated adult spinal cord. J Neuropathol Exp Neurol 1997;56:1191201.

63. Tigges J, Herndon JG, Peters A. Axon terminals on Betz cell somata of area 4 in rhesus monkey throughout adulthood. Anat Rec 1992;232:305-15.

64. Peters A, Moss MB, Sethares C. Effects of aging on myelinated nerve fibers in monkey primary visual cortex. J Comp Neurol 2000;419:364-76.

65. Feldman ML, Peters A. Ballooning of myelin sheaths in normally aged macaques. J Neurocytol 1998;27:605-14.

66. Albert M. Neuropsychological and neurophysiological changes in healthy adult humans across the age range. Neurobiol Aging 1993; 14:623-5.

67. Haug H, Eggers R. Morphometry of the human cortex cerebri and corpus striatum during aging. Neurobiol Aging 1991;12:336-8.

68. Sturrock RR. Changes in neuroglia and myelination in the white matter of aging mice. J Gerontol 1976;31:513-22.

69. Hill RA, Li AM, Grutzendler J. Lifelong cortical myelin plasticity and age-related degeneration in the live mammalian brain. Nat Neurosci 2018;21:683-95.

70. Wang F, Ren SY, Chen JF, Liu K, Li RX, Li ZF, et al. Myelin degeneration and diminished myelin renewal contribute to agerelated deficits in memory. Nat Neurosci 2020;23:481-6.

71. Vanzulli I, Rivera A, Rodríguez-Arellano JJ, Butt AM. Decreased regenerative capacity of oligodendrocyte progenitor cells (NG2glia) in the ageing brain: a vicious cycle of synaptic dysfunction, myelin loss and neuronal disruption? Curr Alzheimer Res 2016;13:413-8.

72. Gutiérrez R, Boison D, Heinemann U, Stoffel W. Decompaction of CNS myelin leads to a reduction of the conduction velocity of action potentials in optic nerve. Neurosci Lett 1995;195:93-6.

73. Aston-Jones G, Rogers J, Shaver RD, Dinan TG, Moss DE. Ageimpaired impulse flow from nucleus basalis to cortex. Nature
1985;318:462-4.

74. Dorfman LJ, Bosley TM. Age-related changes in peripheral and central nerve conduction in man. Neurology 1979;29:38-44.

75. Rogers J, Zornetzer SF, Bloom FE. Senescent pathology of cerebellum: Purkinje neurons and their parallel fiber afferents. Neurobiol Aging 1981;2:15-25.

76. Xi MC, Liu RH, Engelhardt JK, Morales FR, Chase MH. Changes in the axonal conduction velocity of pyramidal tract neurons in the aged cat. Neuroscience 1999;92:219-25.

77. Peters A. The effects of normal aging on myelin and nerve fibers: a review. J Neurocytol 2002;31:581-93.

78. Marques S, Zeisel A, Codeluppi S, van Bruggen D, Mendanha Falcão A, Xiao L, et al. Oligodendrocyte heterogeneity in the mouse juvenile and adult central nervous system. Science 2016;352:1326-9.

79. Askew K, Li K, Olmos-Alonso A, Garcia-Moreno F, Liang Y, Richardson $\mathrm{P}$, et al. Coupled proliferation and apoptosis maintain the rapid turnover of microglia in the adult brain. Cell Rep 2017; 18:391-405.

80. Füger $\mathrm{P}$, Hefendehl JK, Veeraraghavalu $\mathrm{K}$, Wendeln $\mathrm{AC}$, Schlosser C, Obermüller U, et al. Microglia turnover with aging and in an Alzheimer's model via long-term in vivo single-cell imaging. Nat Neurosci 2017;20:1371-6.

81. Réu P, Khosravi A, Bernard S, Mold JE, Salehpour M, Alkass K, et al. The lifespan and turnover of microglia in the human brain. Cell Rep 2017;20:779-84.

82. Damani MR, Zhao L, Fontainhas AM, Amaral J, Fariss RN, Wong WT. Age-related alterations in the dynamic behavior of microglia. Aging Cell 2011;10:263-76.

83. Streit WJ, Sammons NW, Kuhns AJ, Sparks DL. Dystrophic microglia in the aging human brain. Glia 2004;45:208-12.

84. Sierra A, Gottfried-Blackmore AC, McEwen BS, Bulloch K. Microglia derived from aging mice exhibit an altered inflammatory profile. Glia 2007;55:412-24.

85. Xu H, Chen M, Manivannan A, Lois N, Forrester JV. Age-dependent accumulation of lipofuscin in perivascular and subretinal microglia in experimental mice. Aging Cell 2008;7:58-68.

86. Brizzee KR, Sherwood N, Timiras PS. A comparison of cell populations at various depth levels in cerebral cortex of young adult and aged Long-Evans rats. J Gerontol 1968;23:289-97.

87. Morgan TE, Xie Z, Goldsmith S, Yoshida T, Lanzrein AS, Stone $\mathrm{D}$, et al. The mosaic of brain glial hyperactivity during normal ageing and its attenuation by food restriction. Neuroscience 1999;89:687-99.

88. Perry VH, Matyszak MK, Fearn S. Altered antigen expression of microglia in the aged rodent CNS. Glia 1993;7:60-7.

89. Ogura K, Ogawa M, Yoshida M. Effects of ageing on microglia in the normal rat brain: immunohistochemical observations. Neuroreport 1994;5:1224-6.

90. Stuesse SL, Cruce WL, Lovell JA, McBurney DL, Crisp T. Microglial proliferation in the spinal cord of aged rats with a sciatic nerve injury. Neurosci Lett 2000;287:121-4.

91. Miller KR, Streit WJ. The effects of aging, injury and disease on microglial function: a case for cellular senescence. Neuron Glia Biol 2007;3:245-53.

92. Floden AM, Combs CK. Microglia demonstrate age-dependent interaction with amyloid-beta fibrils. J Alzheimers Dis 2011;25:279-93.

93. Harry GJ. Microglia during development and aging. Pharmacol Ther 2013;139:313-26.

94. Caldeira C, Oliveira AF, Cunha C, Vaz AR, Falcão AS, Fernandes A, et al. Microglia change from a reactive to an age-like phenotype with the time in culture. Front Cell Neurosci 2014;8:152.

95. Letiembre M, Hao W, Liu Y, Walter S, Mihaljevic I, Rivest S, et al. Innate immune receptor expression in normal brain aging. 
Neuroscience 2007;146:248-54.

96. Henry CJ, Huang Y, Wynne AM, Godbout JP. Peripheral lipopolysaccharide (LPS) challenge promotes microglial hyperactivity in aged mice that is associated with exaggerated induction of both pro-inflammatory IL-1beta and anti-inflammatory IL-10 cytokines. Brain Behav Immun 2009;23:309-17.

97. Ye SM, Johnson RW. An age-related decline in interleukin-10 may contribute to the increased expression of interleukin-6 in brain of aged mice. Neuroimmunomodulation 2001;9:183-92.

98. Mosher KI, Wyss-Coray T. Microglial dysfunction in brain aging and Alzheimer's disease. Biochem Pharmacol 2014;88:594-604.

99. Wong WT. Microglial aging in the healthy CNS: phenotypes, drivers, and rejuvenation. Front Cell Neurosci 2013;7:22.

100. Conde JR, Streit WJ. Microglia in the aging brain. J Neuropathol Exp Neurol 2006;65:199-203.

101. Capilla-Gonzalez V, Cebrian-Silla A, Guerrero-Cazares H, Garcia-Verdugo JM, Quiñones-Hinojosa A. Age-related changes in astrocytic and ependymal cells of the subventricular zone. Glia 2014;62:790-803.

102. Brawer JR, Walsh RJ. Response of tanycytes to aging in the median eminence of the rat. Am J Anat 1982;163:247-56.

103. Biondi G. Ein neuer histologischer Befund am Epithel des Plexus chorioideus. Z ges Neurol Psychiatrie 1933;144:161-5.

104. Serot JM, Foliguet B, Bene MC, Faure GC. Choroid plexus and ageing in rats: a morphometric and ultrastructural study. Eur J Neurosci 2001;14:794-8.

105. Bargmann W, Katritsis E. Über die sog. Filamente und das Pigment im Plexus chorioideus des Menschen. Z Zellforsch Mikrosk Anat 1966;75:366-70.

106. Oksche A, Kirschstein H. Entstehung und Ultrastruktur der Biondi-Korper in den Plexus chorioidei des menschen (Biopsiematerial. Z Zellforsch Mikrosk Anat 1972;124:320-41.

107. Wen GY, Wisniewski HM, Kascsak RJ. Biondi ring tangles in the choroid plexus of Alzheimer's disease and normal aging brains: a quantitative study. Brain Res 1999;832:40-6.

108. Oksche A, Liesner R, Tigges J, Tigges M. Intraepithelial inclusions resembling human biondi bodies in the choroid plexus of an aged chimpanzee. Cell Tissue Res 1984;235:467-9.

109. Preston JE. Ageing choroid plexus-cerebrospinal fluid system. Microsc Res Tech 2001;52:31-7.

110. Damkier HH, Brown PD, Praetorius J. Cerebrospinal fluid secretion by the choroid plexus. Physiol Rev 2013;93:1847-92.

111. Grover-Johnson N, Spencer PS. Peripheral nerve abnormalities in aging rats. J Neuropathol Exp Neurol 1981;40:155-65.

112. van den Bosch de Aguilar P, Goemaere-Vanneste J, Klosen P, Terao E. Ageing changes of spinal ganglion neurons. In: K Fujisawa, Y Morimatsu editors. Development and Involution of Neurones. Tokyo: Japan Scientific Societies Press; 1992. p. 10950.

113. Choo D, Malmgren LT, Rosenberg SI. Age-related changes in Schwann cells of the internal branch of the rat superior laryngeal nerve. Otolaryngol Head Neck Surg 1990;103:628-36.

114. Fiori MG. Intranuclear inclusions in Schwann cells of aged fowl ciliary ganglia. J Anat 1987;154:201-14.

115. Adinolfi AM, Yamuy J, Morales FR, Chase MH. Segmental demyelination in peripheral nerves of old cats. Neurobiol Aging 1991;12:175-9.

116. Ceballos D, Cuadras J, Verdú E, Navarro X. Morphometric and ultrastructural changes with ageing in mouse peripheral nerve. $\mathrm{J}$ Anat 1999;195:563-76.

117. Griffiths IR, Duncan ID. Age changes in the dorsal and ventral lumbar nerve roots of dogs. Acta Neuropathol 1975;32:75-85.

118. Knox CA, Kokmen E, Dyck PJ. Morphometric alteration of rat myelinated fibers with aging. J Neuropathol Exp Neurol 1989;48:119-39.
119. Robertson A, Day B, Pollock M, Collier P. The neuropathy of elderly mice. Acta Neuropathol 1993;86:163-71.

120. Sharma AK, Bajada S, Thomas PK. Age changes in the tibial and plantar nerves of the rat. J Anat 1980;130:417-28.

121. Behse F, Buchthal F. Normal sensory conduction in the nerves of the leg in man. J Neurol Neurosurg Psychiatry 1971;34:404-14.

122. Downie AW, Newell DJ. Sensory nerve conduction in patients with diabetes mellitus and controls. Neurology 1961;11:876-82.

123. LaFratta CW, Canestrari R. A comparison of sensory and motor nerve conduction velocities as related to age. Arch Phys Med Rehabil 1966;47:286-90.

124. Norris AH, Shock NW, Wagman IH. Age changes in the maximum conduction velocity of motor fibers of human ulnar nerves. J Appl Physiol 1953;5:589-93.

125. Wagman IH, Lesse H. Maximum conduction velocities of motor fibers of ulnar nerve in human subjects of various ages and sizes. J Neurophysiol 1952;15:235-44.

126. Pannese E. The satellite cells of the sensory ganglia. Adv Anat Embryol Cell Biol 1981;65:1-111.

127. Martinelli C, Sartori P, De Palo S, Ledda M, Pannese E. The perineuronal glial tissue of spinal ganglia. Quantitative changes in the rabbit from youth to extremely advanced age. Anat Embryol 2006;211:455-63.

128. Pannese E, Procacci P, Ledda M, Conte V. Age-related reduction of the satellite cell sheath around spinal ganglion neurons in the rabbit J Neurocytol 1996;25:137-46.

129. Pannese E, Ledda M, Martinelli C, Sartori P. Age-related decrease of the perineuronal satellite cell number in the rabbit spinal ganglia. J Peripher Nerv Syst 1997;2:77-81.

130. Pannese E. Biology and pathology of perineuronal satellite cells in sensory ganglia. Adv Anat Embryol Cell Biol 2018;226:1-83.

131. Sylvia AL, Rosenthal M. Effects of age on brain oxidative metabolism in vivo. Brain Res 1979;165:235-48.

132. van den Bosch de Aguilar P, Vanneste J. The microenvironment of the spinal ganglion neuron in the rat during aging. Exp Neurol 1983;81:294-307.

133. Martinelli C, Sartori P, De Palo S, Ledda M, Pannese E. Increase in number of the gap junctions between satellite neuroglial cells during lifetime: an ultrastructural study in rabbit spinal ganglia from youth to extremely advanced age. Brain Res Bull 2005;67:19-23.

134. Huang TY, Hanani M, Ledda M, De Palo S, Pannese E. Aging is associated with an increase in dye coupling and in gap junction number in satellite glial cells of murine dorsal root ganglia. Neuroscience 2006;137:1185-92.

135. Procacci P, Magnaghi V, Pannese E. Perineuronal satellite cells in mouse spinal ganglia express the gap junction protein connexin43 throughout life with decline in old age. Brain Res Bull 2008;75:562-9.

136. Hirbec H, Deglon N, Foo LC, Goshen I, Grutzendler J, Hangen E, et al. Emerging technologies to study glial cells. Glia 2020;68:1692-728.

137. O'Callaghan JP, Miller DB. The concentration of glial fibrillary acidic protein increases with age in the mouse and rat brain. Neurobiol Aging 1991;12:171-4.

138. Kohama SG, Goss JR, Finch CE, McNeill TH. Increases of glial fibrillary acidic protein in the aging female mouse brain. Neurobiol Aging 1995;16:59-67.

139. Jalenques I, Albuisson E, Despres G, Romand R. Distribution of glial fibrillary acidic protein (GFAP) in the cochlear nucleus of adult and aged rats. Brain Res 1995;686:223-32.

140. Rozovsky I, Finch CE, Morgan TE. Age-related activation of microglia and astrocytes: in vitro studies show persistent phenotypes of aging, increased proliferation, and resistance to downregulation. Neurobiol Aging 1998;19:97-103. 
141. Porchet R, Probst A, Bouras C, Draberova E, Draber P, Riederer BM. Analysis of glial acidic fibrillary protein in the human entorhinal cortex during aging and in Alzheimer's disease. Proteomics 2003;3:1476-85.

142. Nichols NR, Day JR, Laping NJ, Johnson SA, Finch CE. GFAP mRNA increases with age in rat and human brain. Neurobiol Aging 1993;14:421-9.

143. Kane CJ, Sims TJ, Gilmore SA. Astrocytes in the aged rat spinal cord fail to increase GFAP mRNA following sciatic nerve axotomy. Brain Res 1997;759:163-5.

144. Sheng JG, Mrak RE, Rovnaghi CR, Kozlowska E, Van Eldik LJ, Griffin WS. Human brain S100 beta and S100 beta mRNA expression increases with age: pathogenic implications for Alzheimer's disease. Neurobiol Aging 1996;17:359-63.

145. Duncombe J, Lennen RJ, Jansen MA, Marshall I, Wardlaw JM, Horsburgh K. Ageing causes prominent neurovascular dysfunction associated with loss of astrocytic contacts and gliosis. Neuropathol Appl Neurobiol 2017;43:477-91.

146. Kress BT, Iliff JJ, Xia M, Wang M, Wei HS, Zeppenfeld D, et al. Impairment of paravascular clearance pathways in the aging brain. Ann Neurol 2014;76:845-61.

147. Lalo U, Rasooli-Nejad S, Pankratov Y. Exocytosis of gliotransmitters from cortical astrocytes: implications for synaptic plasticity and aging. Biochem Soc Trans 2014;42:1275-81.

148. Shetty AK, Hattiangady B, Shetty GA. Stem/progenitor cell proliferation factors FGF-2, IGF-1, and VEGF exhibit early decline during the course of aging in the hippocampus: role of astrocytes. Glia 2005;51:173-86.

149. Bellaver B, Souza DG, Souza DO, Quincozes-Santos A. Hippocampal astrocyte cultures from adult and aged rats reproduce changes in glial functionality observed in the aging brain. Mol Neurobiol 2017;54:2969-85.

150. Rogers J, Luber-Narod J, Styren SD, Civin WH. Expression of immune system-associated antigens by cells of the human central nervous system: relationship to the pathology of Alzheimer's disease. Neurobiol Aging 1988;9:339-49.

151. Streit WJ, Sparks DL. Activation of microglia in the brains of humans with heart disease and hypercholesterolemic rabbits. J Mol Med 1997;75:130-8.

152. Sheffield LG, Berman NE. Microglial expression of MHC class II increases in normal aging of nonhuman primates. Neurobiol Aging 1998;19:47-55.

153. Kullberg S, Aldskogius H, Ulfhake B. Microglial activation, emergence of ED1-expressing cells and clusterin upregulation in the aging rat CNS, with special reference to the spinal cord. Brain Res 2001;899:169-86.

154. Frank MG, Barrientos RM, Biedenkapp JC, Rudy JW, Watkins LR, Maier SF. mRNA up-regulation of MHC II and pivotal proinflammatory genes in normal brain aging. Neurobiol Aging 2006;27:717-22.

155. Griffin R, Nally R, Nolan Y, McCartney Y, Linden J, Lynch MA. The age-related attenuation in long-term potentiation is associated with microglial activation. J Neurochem 2006;99:1263-72.
156. Hart AD, Wyttenbach A, Perry VH, Teeling JL. Age related changes in microglial phenotype vary between CNS regions: grey versus white matter differences. Brain Behav Immun 2012;26:754-65.

157. Stichel CC, Luebbert H. Inflammatory processes in the aging mouse brain: participation of dendritic cells and T-cells. Neurobiol Aging 2007;28:1507-21.

158. Wong AM, Patel NV, Patel NK, Wei M, Morgan TE, de Beer $\mathrm{MC}$, et al. Macrosialin increases during normal brain aging are attenuated by caloric restriction. Neurosci Lett 2005;390:76-80.

159. VanGuilder HD, Bixler GV, Brucklacher RM, Farley JA, Yan H, Warrington JP, et al. Concurrent hippocampal induction of MHC II pathway components and glial activation with advanced aging is not correlated with cognitive impairment. J Neuroinflammation 2011;8:138.

160. Safaiyan S, Kannaiyan N, Snaidero N, Brioschi S, Biber K, Yona $\mathrm{S}$, et al. Age-related myelin degradation burdens the clearance function of microglia during aging. Nat Neurosci 2016;19:995-8.

161. Sheng JG, Mrak RE, Griffin WS. Enlarged and phagocytic, but not primed, interleukin-1 alpha-immunoreactive microglia increase with age in normal human brain. Acta Neuropathol 1998;95:229-34.

162. Maher FO, Nolan Y, Lynch MA. Downregulation of IL-4induced signalling in hippocampus contributes to deficits in LTP in the aged rat. Neurobiol Aging 2005;26:717-28.

163. Murray CA, Lynch MA. Evidence that increased hippocampal expression of the cytokine interleukin-1 beta is a common trigger for age- and stress-induced impairments in long-term potentiation. J Neurosci 1998;18:2974-81.

164. Xie Z, Morgan TE, Rozovsky I, Finch CE. Aging and glial responses to lipopolysaccharide in vitro: greater induction of IL1 and IL-6, but smaller induction of neurotoxicity. Exp Neurol 2003;182:135-41.

165. Njie EG, Boelen E, Stassen FR, Steinbusch HW, Borchelt DR, Streit WJ. Ex vivo cultures of microglia from young and aged rodent brain reveal age-related changes in microglial function. Neurobiol Aging 2012;33:195 e1-e12.

166. Ye SM, Johnson RW. Increased interleukin-6 expression by microglia from brain of aged mice. $J$ Neuroimmunol 1999;93:139-48.

167. Hinman JD, Duce JA, Siman RA, Hollander W, Abraham CR. Activation of calpain- 1 in myelin and microglia in the white matter of the aged rhesus monkey. J Neurochem 2004;89:430-41.

168. Sloane JA, Hinman JD, Lubonia M, Hollander W, Abraham CR. Age-dependent myelin degeneration and proteolysis of oligodendrocyte proteins is associated with the activation of calpain- 1 in the rhesus monkey. J Neurochem 2003;84:157-68.

169. Wynne AM, Henry CJ, Huang Y, Cleland A, Godbout JP. Protracted downregulation of $\mathrm{CX}_{3} \mathrm{CR} 1$ on microglia of aged mice after lipopolysaccharide challenge. Brain Behav Immun 2010;24:1190-201.

170. Nolan Y, Maher FO, Martin DS, Clarke RM, Brady MT, Bolton $\mathrm{AE}$, et al. Role of interleukin-4 in regulation of age-related

Received for publication: 18 March 2021. Accepted for publication: 27 May 2021.

This work is licensed under a Creative Commons Attribution-NonCommercial 4.0 International License (CC BY-NC 4.0).

CC Copyright: the Author(s), 2021

Licensee PAGEPress, Italy

European Journal of Histochemistry 2021; 65(s1):3249

doi:10.4081/ejh.2021.3249 